\title{
PENGGUNAAN AKUNTANSI FORENSIK DALAM PENYELESAIAN KASUS KEPAILITAN (Bankrupt)
}

\author{
Oleh: \\ R. Nelly Nur Apandi \\ (Program Studi Akuntansi FPEB Universitas Pendidikan Indonesia) \\ Yudha Pradista \\ (Program Studi Akuntansi FPEB Universitas Pendidikan Indonesia)
}

\begin{abstract}
This research aim to know how bankrupt process and applying of forensic accountancy in bankrupt. Besides to know constraints any kind of faced in applying forensic accountancy in finishing case of bankrupt. This study uses qualitative methods. Informant this research consists of curators, civil servant, forensic accountants and Auditors. Result of this research indicate that forensic accountancy have role in assisting to finish case of bankrupt. This matter can be seen from some process or step is solving of case of done bankrupt in justice of commercial needing forensic accountancy. The first, checking off receivable and liability at litigation to prove that debtor really is having of debt to all creditor so that ascertain justice in deciding bankrupt an company. Second, enumeration of bankruptasset to data exist in document, financial statement, and debtor boldness with direct inspection in field. Third, checking off receivable and liability at the time of creditor meeting to know really conducted receivable and liability amount in agreement between creditor and debtor. Fourth, at the time of division of bankrupt asset to ascertain sequence of is division of between separatist creditor, preferential, and congruence seen the existence of guarantee or do not at the time of agreement of receivable and liability. Fifth, detecting the existence of indication of fraud that happened at case of bankrupt.
\end{abstract}

\section{Keyword : Forensic Accounting, Bankrupt and Constraint}

\section{Pendahuluan}

Dalam menjalankan bisnisnya, suatu perusahaan pasti ingin mendapatkan hasil yang maksimal. Perusahaan yang telah mencapai targetnya, tentu ingin mengembangkan usahanya agar dapat mencapai target berikutnya yang lebih besar. Suatu perusahaan memiliki beberapa sumber dana untuk mengembangkan usahanya, baik itu dan yang bersumber dari internal maupun dana yang bersumber dari eksternal. Dana yang berasal dari internal perusahaan contohnya seperti laba penjualan, sedangkan dana yang berasal dari eksternal contohnya dana yang diterima dari investor maupun pinjaman dari bank dan lembaga keuangan bukan bank. Dengan adanya tambahan dana yang diterima oleh perusahaan, diharapkan dapat memudahkan dalam mengembangkan usahanya.

Dalam mengembangkan usahanya, ada kemungkinan perusahaan tersebut tidak berhasil. Banyak faktor yang mempengaruhi suatu perusahaan berhasil atau tidak. Ketika perusahaan tidak berhasil dalam mengembangkan usaha dan meningkatkan laba, maka akan terjadi kemacetan dalam membayar utang kepada 
kreditor. Apabila keadaan ini terus berlanjut, maka perusahaan akan mengalami kepailitan.

Menurut Rachmadi Usman (2004: 12) kepailitan adalah keadaan dimana seorang debitur tidak mampu melunasi utang-utangnya pada saat utang tersebut jatuh tempo. Kasus kepailitan yang paling menyita perhatian adalah suatu BUMN yaitu PT Dirgantara Indonesia yang dinyatakan pailit oleh Pengadilan Niaga Jakarta Pusat pada 4 September 2007, walaupun keputusan pailit tersebut dibatalkan oleh Mahkamah Agung pada 24 Oktober 2007. Contoh kasus lainnya adalah kepailitan yang dialami PT Metro Batavia (Batavia Air) dikarenakan utang yang jatuh tempo tidak kunjung dibayar sebesar US\$4,68 juta. Gugatan pailit ini diajukan oleh International Lease Finance Corporation (ILFC). Keputusan pailit PT Metro Batavia (Batavia Air) dikeluarkan oleh Pengadilan Niaga Jakarta Pusat dalam putusannya No. 77/pailit/2012/PN.NIAGA.JKT.PST pada tanggal 30 Januari 2013. (Maria Yuniar, 2013)

Kepailitan dapat terjadi ketika aset yang dimiliki oleh perusahaan lebih kecil daripada utang yang harus dibayarkan kepada para kreditor. Oleh karena itu kemungkinan adanya perselisihan antara kreditor dengan kreditor lainnya dalam mengakui aset yang seharusnya diterima oleh masing-masing kreditor. Selain itu kepailitan juga dapat terjadi ketika aset yang dimiliki oleh perusahaan lebih besar daripada utang yang harus dibayarkan kepada para kreditor. Sehingga kemungkinan terjadi perselisihan antara debitur dan para kreditor dalam pembagian aset, karena dalam situasi seperti ini debitur masih memiliki hak terhadap kelebihan aset setelah dibayarkan utang kepada para kreditor.

Adrian Sutedi (2009: 26) menyebutkan ada beberapa faktor perlunya pengaturan mengenai kepailitan dan penundaan kewajiban pembayaran utang, yakni pertama, untuk menghindari perebutan harta debitur apabila dalam waktu yang sama ada beberapa kreditor yang menagih piutangnya. Kedua, untuk menghindari adanya kreditor pemegang hak jaminan kebendaan yang menuntut haknya dengan cara menjual barang milik debitur tanpa memerhatikan kepentingan debitur atau para kreditor lainnya. Ketiga, untuk menghindari adanya kecurangan-kecurangan yang dilakukan oleh salah seorang kreditor atau debitur sendiri. Misalnya, debitur berusaha untuk memberi keuntungan kepada seorang atau beberapa orang kreditor tertentu sehingga kreditor lainnya dirugikan, atau adanya perbuatan curang dari debitur untuk melarikan semua harta kekayaannya dengan maksud untuk melepaskan tanggung jawabnya terhadap para kreditor.

Perkara kepailitan di Indonesia cukup banyak setiap tahunnya yang masuk ke Pengadilan Niaga. Hal tersebut dapat dilihat dari jumlah perkara yang masuk ke Pengadilan Niaga Jakarta Pusat pada tabel berikut.

Tabel 1Daftar Perkara Kepailitan Tahun 2010-2012

Penyelesaian masalah kepailitan dapat ditempuh melalui pembicaraan antara debitur dan kreditor melalui mediasi maupun ditempuh dengan jalur hukum dengan mengajukan ke pengadilan niaga. Berdasarkan data yang diperoleh dari Pengadilan Niaga Jakarta Pusat, perkara kepailitan yang masuk dari tahun ke tahun mengalami fluktuasi tetapi tidak terlalu signifikan. Pada tahun 2010 terdapat 86 perkara yang masuk. Pada tahun 2011 lebih banyak 1 perkara menjadi 87 perkara yang masuk. Pada tahun 2012 mengalami penurunan menjadi 76 perkara yang masuk. Hal ini menunjukkan bahwa minat penyelesaian masalah kepailitan di pengadilan negeri masih tetap tinggi. Di Indonesia hukum yang 
mengatur tentang hal tersebut adalah Undang-Undang No. 37 Tahun 2004 Tentang Kepailitan dan Penundaan Kewajiban Pembayaran Utang. Pada awalnya pengadilan niaga hanya beroperasi pada Pengadilan Negeri Jakarta Pusat, namun setelah dikeluarkannya Keputusan Presiden No. 97 Tahun 1999, pemerintah membentuk pengadilan niaga pada empat wilayah pengadilan negeri lainnya, yaitu di Pengadilan Negeri Makassar, Pengadilan Negeri Medan, Pengadilan Negeri Surabaya, dan Pengadilan Negeri Semarang.

Permohonan kepailitan suatu perusahaan menurut Adrian Sutedi (2009: 39) dapat dilakukan oleh beberapa pihak. Pertama, pihak debitur sebagai pemohon kepailitan. Seorang debitur dapat mengajukan permohonan kepailitan apabila mempunyai dua atau lebih kreditor (lebih dari satu kreditor) dan debitur sedikitnya tidak membayar satu utang yang telah jatuh waktu dan telah dapat ditagih. Namun, ketentuan tersebut membuka kemungkinan bagi debitur yang nakal untuk melakukan rekayasa demi kepentingannya. Kedua, pihak kreditor sebagai pemohon kepailitan. Kreditor dapat mengajukan permohonan kepailitan apabila debitur mempunyai dua atau lebih kreditor dan sedikitnya tidak membayar satu utang yang telah jatuh tempo dan dapat ditagih. Ketiga, pihak kejaksaan sebagai pemohon kepailitan. Menurut pasal 2 ayat (2) Undang-Undang No. 37 Tahun 2004 menentukan bahwa permohonan pernyataan pailit dapat diajukan oleh kejaksaan untuk kepentingan umum. Dimana tata cara permohonan kepailitan sama dengan permohonan yang diajukan oleh debitur dan kreditor. Pada dasarnya kepailitan dapat diajukan oleh semua jenis kreditor. Tidak ada batasan mengenai kualifikasi kreditor yang dapat mengajukannya. Sepanjang kreditor tersebut dapat membuktikan secara sederhana bahwa ada lebih dari satu utang dan salah satunya telah jatuh tempo, maka secara formal, hakim wajib menyatakan debitur pailit. Pihak-pihak yang terlibat di Pengadilan Niaga terdiri dari debitur, kreditor, hakim, jaksa, dan kurator.

Kurator adalah orang yang mengurusi kegiatan debitur setelah pernyataan pailit. Pengangkatan kurator yang akan membereskan dan mengurus harta debitur dilakukan oleh pengadilan. Seseorang yang dapat menjadi kurator adalah sarjana hukum atau sarjana ekonomi jurusan akuntansi. Dalam menjalankan tugasnya untuk menghitung aset debitur, seorang kurator menggunakan keahlian khusus yang disebut akuntansi forensik. Akuntansi forensik adalah praktik khusus bidang akuntansi yang menggambarkan keterlibatan yang dihasilkan dari perselisihan aktual atau yang diantisipasi atau ligitasi. Dimana akuntansi forensik ini pada awalnya merupakan perpaduan yang sederhana antara akuntansi dan hukum, tetapi pada kasus yang lebih rumit ada tambahan ilmu yang terkandung dalam akuntansi forensik yaitu ilmu audit. Sedangkan audit investigatif merupakan upaya pembuktian, umumnya pembuktian ini berakhir di pengadilan dan ketentuan hukum acara yang berlaku.

Pada mulanya, di Amerika Serikat, akuntansi forensik digunakan untuk menentukan pembagian warisan atau mengungkapkan motif pembunuhan. Misalnya pembunuhan isteri oleh suami untuk mendapatkan hak waris atau klaim asuransi atau pembunuhan mitra dagang untuk menguasai perusahaan. Ilmu akuntansi forensik sudah ada sejak kasus Al Capone yang terungkap oleh seorang akuntan forensik yang bernama Frank J. Wilson pada tahun 1931. Kemudian dengan adanya undang-undang Sarbanes-Oxley Act tahun 2002 di Amerika Serikat disebut sebagai salah satu faktor terpenting dalam perkembangan 
akuntansi forensik. Akuntansi forensik sebenarnya telah dipraktekkan di Indonesia sejak lama, namun bidang akuntansi forensik ini mulai berkembang di Indonesia setelah adanya krisis ekonomi yang melanda Indonesia pada tahun 1998. Akuntansi forensik dilaksanakan oleh berbagai lembaga seperti Badan Pemeriksa Keuangan (BPK), Komisi Pemberantasan Korupsi (KPK), Pusat Pelaporan dan Analisis Transaksi Keuangan (PPATK), Badan Pengawasan Keuangan dan Pembangunan (BPKP), Bank Dunia (untuk proyek-proyek pinjamannya), dan kantor-kantor akuntan publik (KAP) di Indonesia.

Perkara yang masuk ke Pengadilan Niaga tidak semua dikabulkan untuk dipailitkan. Ada beberapa perkara yang mengalami gagal pailit dan pencabutan perkara. Daftar jumlah perusahaan yang mengalami pailit dapat dilihat dari tabel berikut.

Tabel2Keputusan Kepailitan di Pengadilan Niaga Jakarta Pusat Tahun 2012

Dari tabel diatas dapat kita ketahui bahwa perusahaan yang mengalami kepailitan di Pengadilan Niaga Jakarta Pusat pada tahun 2012 mencapai 33 perusahaan. Sehingga diperlukannya akuntansi forensik dalam menghitung dan mencari aset yang dimiliki oleh debitur agar tidak ada asetnya yang tidak terhitung dan pembagian harta yang sesuai proporsinya kepada semua kreditor. Selain itu dengan adanya akuntansi forensik diharap dapat membantu dalam penyelesaian masalah kepailitan di pengadilan niaga.

Hasil penelitian Beaver (1966) dalam Adrian Sutedi (2009: 11) merupakan salah satu penelitian yang sering dijadikan acuan utama dalam penelitian tentang corporate failure. Beaver memandang perusahaan sebagai reservoir of liquid aset, which supplied by inflows and drained by outflows. Beaver menggunakan 30 jenis rasio keuangan yang digunakan pada 79 pasang perusahaan yang pailit dan tidak pailit. Memakai univatiate discriminant analysis sebagai alat uji statistik. Beaver menyimpulkan bahwa rasio working capital funds flow/total asets dan net income/total asets mampu membedakan perusahaan yang akan pailit dengan yang tidak pailit secara tepat, masing-masing sebesar $90 \%$ dan $80 \%$ dari sampel yang digunakan.

Penelitian lainnya yang dilakukan oleh Ratih Siti (2011) menyimpulkan bahwa penerapan akuntansi forensik memiliki pengaruh positif dan signifikan terhadap kompetensi bukti tindak pidana korupsi. Bruno M. Franceschetti dan Claudia Koschtial (2013) menyatakan dalam penelitiannya perusahaan yang bankrupt cenderung untuk melakukan manipulasi laporan keuangan. Penelitian tersebut mencoba untuk menguatkan jurnal yang diterbitkan oleh Delloite yang menyatakan bahwa perusahaan yang berpotensi mengalami kepailitan tiga kali lebih mungkin melakukan fraud dibandingkan perusahaan yang tidak mengalami kepailitan.

Jumansyah, dkk. (2011) menyatakan bahwa akuntansi forensik dapat membantu menyelesaikan kasus-kasus hukum dengan cara membantu para penegak hukum untuk melakukan perhitungan dan pengungkap kos kecurangan, mendeteksi penyebab terjadinya kecurangan, menemukan petunjuk awal (indicia of fraud) terjadinya kecurangan, dan mendeteksi kira-kira waktu kecurangan dapat terungkap dan membedakan kecurangan yang terungkap melalui tip atau secara kebetulan.

Selama ini, masih sedikit orang yang mengerti akan peran akuntansi forensik dalam praktik kepailitan. Karena kita lebih banyak mendengar akuntansi 
forensik dalam menyelesaikan kasus korupsi. Berdasarkan uraian diatas, maka permasalahan penelitian ini adalah (1) Bagaimana proses peradilan kepailitan di pengadilan niaga; (2) Bagaimana peran akuntansi forensik dan penerapannya dalam praktik kepailitan pada pengadilan niaga; (3) Kendala-kendala apa saja yang dihadapi dalam menerapkan akuntansi forensik dalam praktik kepailitan.

\section{Kajian Pustaka}

Persaingan dunia usaha yang semakin kompetitif mengakibatkan para pelaku usaha cenderung melakukan spekulasi dalam menjalankan bisnisnya. Teori investasi menyebutkan bahwa resiko berbanding lurus dengan hasil yang didapatkan. Keinginan untuk mencapai profit yang maksimal, kadang mengabaikan proses penilaian resiko. Sehingga ketidakmatangan dalam menganalisis resiko yang akan dihadapi oleh perusahaan, akan menyebabkan perusahaan mengalami bankrupt. Bankrupt terjadi karena ketidak mampuan perusahaan dalam menghasilkan profit dan/ atau tidak mampu dalam membayar utang jangka pendek dan panjang.

Ketika perusahaan tidak mampu membayar kewajiban kepada kreditor, maka kreditor pada umumnya akan berusaha mengambil alih jaminan atas utang yang telah disepakati. Kadangkala perusahaan untuk menambah modal, tidak hanya mendapat pinjaman dari satu kreditor, tetapi dapat lebih dari satu kreditor. Apabila pada saat yang bersamaan perusahaan tidak dapat membayar utang kepada para kreditor tersebut, hal itu dapat memicu adanya perselisihan antar kreditor dalam hal pembayaran utang. Jika hal ini terjadi, maka perselisihan itu dapat diselesaikan melalui Pengadilan Niaga, ataupun melalui cara di luar pengadilan, contohnya mediasi, arbitrase, konsiliasi, dan negosiasi.

Dalam Pengadilan Niaga, status kepailitan tidak selalu diajukan oleh kreditor, tetapi debitur pun dapat memohon kepada pengadilan untuk mendapatkan keputusan kepailitan. Pada proses penyelesaian kepailitan dalam Pengadilan Niaga terdapat beberapa pihak yang terlibat, diantaranya jaksa, kreditor, debitur, dan kurator.

Kurator menurut Adrian Sutedi (2009: 60) adalah orang yang mengurus kegiatan debitur setelah adanya pernyataan pailit dari penngadilan. Sesuai dengan Pasal 69 Undang-Undang Kepailitan, kurator mempunyai tugas melakukan pengurusan dan/ atau pemberesan harta pailit. Dalam menyelesaikan tugasnya, kurator harus memiliki keahlian di bidang akuntansi, hukum, dan audit atau biasa disebut dengan akuntansi forensik.

Menurut Theodorus M. Tuanakotta (2007: 1) akuntansi forensik merupakan disiplin ilmu baru yang menggabungkan antara akuntansi, audit dan hukum. Bruno M. Franceschetti dan Claudia Koschtial (2013) menyatakan dalam penelitiannya perusahaan yang bankrupt cenderung untuk melakukan manipulasi laporan keuangan. Penelitian tersebut mencoba untuk menguatkan jurnal yang dikeluarkan oleh Delloite yang menyatakan bahwa perusahaan yang berpotensi mengalami bankrupt tiga kali lebih mungkin melakukan fraud dibandingkan perusahaan yang tidak mengalami bankrupt.

Jumansyah, dkk. (2011) menyatakan bahwa akuntansi forensik dapat membantu menyelesaikan kasus-kasus hukum dengan cara membantu para penegak hukum untuk melakukan perhitungan dan pengungkap kos kecurangan, mendeteksi penyebab terjadinya kecurangan, menemukan petunjuk awal (indicia 
of fraud) terjadinya kecurangan, dan mendeteksi kira-kira waktu kecurangan dapat terungkap dan membedakan kecurangan yang terungkap melalui tip atau secara kebetulan.

\section{Metode Penelitian}

Pendekatan penelitian yang digunakan dalam penelitian ini adalah penelitian deskriptif kualitatif. Format deskriptif kualitatif studi kasus tidak memiliki ciri seperti air (menyebar di permukaan), tetapi memusatkan diri pada suatu unit tertentu dari berbagai fenomena. Dari ciri yang demikian memungkinkan studi ini dapat amat mendalam dan demikian bahwa kedalaman data yang menjadi pertimbangan dalam penelitian model ini (Burhan Bungin, 2010: 68). Dengan desain penelitian menggunakan deskriptif kualitatif, penulis mengharapkan dapat menggali lebih dalam bagaimana peranan akuntansi forensik dalam praktik kepailitan.

Menurut Lofland dan Lofland (1984: 47) dalam Moleong (2010: 157) sumber data utama dalam penelitian kualitatif ialah kata-kata, dan tindakan, selebihnya adalah data tambahan seperti dokumen dan lain-lain. Kata-kata dan tindakan didapatkan dari narasumber yang bersangkutan dengan penerapan akuntansi forensik dalam Pengadilan Niaga.Adapun teknik pengumpulan data pada penelitian ini dilakukan dengan wawancara mendalam (in-depth interview), observasi, dan dokumen.Penentuan informan penelitian dengan menggunakan cara key person.

Sugiyono (2011: 335) menjelaskan bahwa analisis data adalah proses mencari dan menyusun secara sistematis data yang diperoleh dari hasil wawancara, catatan lapangan, dan dokumentasi, dengan cara mengorganisasikan data ke dalam kategori, menjabarkan ke dalam unit-unit, melakukan sintesa, menyusun ke dalam pola, memilih mana yang penting dan yang akan dipelajari, dan membuat kesimpulan sehinngga mudah difahami oleh diri sendiri maupun orang lain.Dalam penelitian ini penulis menganalisis data menggunakan model Miles and Huberman. Analisis data dalam penelitian kualitatif, dilakukan pada saat pengumpulan data berlangsung, dan setelah selesai pengumpulan data dalam periode tertentu. Teknis analisis tersebut melalui beberapa tahap, yaitu (1) Data Reduction (Reduksi Data); (2) Data Display (Penyajian Data); (3) Penarikan Kesimpulan: Temuan Sementara; (4) Melakukan Verifikasi; (5) Penarikan Kesimpulan Akhir Sebagai Temuan Penelitian.

Uji keabsahan data dalam penelitian kualitatif menurut Sugiyono (2012: 458) meliputi uji credibility (validitas internal), transferability (validitas eksternal), dependability (reliabilitas), dan confirmability (obyektivitas).Wiliam Wiersma (1986) dalam Sugiyono (2011: 372) menjelaskan 'triangulation is qualitative cross-validation. It assesses the sufficiency of the data according to the convergence of multiple data sources or multiple data collection procedures'. Dimana triangulasi dalam pengujian kredibiltas data dilakukan dengan pengecekan data dari berbagai sumber, berbagai cara, dan berbagai waktu. Dalam pengujian kredibilitas data pada penelitian ini dilakukan dengan menggunakan teknik triangulasi dengan sumber dan triangulasi teknik.

\section{Hasil penelitian dan Pembahasan}


Suatu permohonan kepailitan dapat dikabulkan apabila adanya fakta atau adanya bukti yang menyatakan bahwa debitur benar-benar mempunyai utang yang sudah jatuh tempo. Hal ini dilakukan dengan pencocokan bukti yang dilakukan debitur dan kreditor pada saat awal persidangan. Hal tersebut juga disampaikan oleh informan 2 sebagai berikut: "Kalau sudah ada bukti utang yang tidak dapat dibayar, yang penting ada dua kreditor, maka dinyatakan pailit. Ini karena ada pembuktian standar dalam syarat mempailitkan sebuah perusahaan. Apabila perusahaan tersebut benar tidak bisa membayar, maka dikatakan bangkrut atau dengan kata lain insolvent."

Hal senada juga disampaikan oleh informan 1 bagaimana perusahaan dapat diajukan pailit ke pengadilan niaga seperti kutipan wawancara sebagai berikut: "Ketika dapat dibuktikan adanya dua orang kreditor dan salah satu utangnya sudah dapat ditagih, maka perusahaan tersebut dapat dikatakan pailit. Ada perusahaan yang benar tidak bisa membayar utang tersebut, ada juga yang dikarenakan persaingan bisnis dimana biasanya perusahaan ini memiliki aset yang lebih besar daripada utangnya"

Lalu informan 6 menguatkan bahwa syarat yang sederhana dalam proses keputusan pailit: "Jadi ketika perkara masuk, dan perusahaan mempunyai dua utang yang jatuh tempo yang sudah dapat ditagih, baru dapat dipailitkan. Harus ada rapat kreditor pertama dulu untuk didata semua tagihan berapa yang masuk, kemudian diverifikasi dulu utang piutang tersebut. Apabila debitur dan kreditor tidak menemui titik temu dalam upaya perdamaian membayar utang piutang tersebut, maka insolvent, yaitu dinyatakan bahwa dia dalam keadaan berhenti membayar."

Hasil reduksi catatan lapangan yang dikumpulkan peneliti ketika melakukan wawancara dengan informan mengenai proses putusan kepailitan ke Pengadilan Niaga yang berhasil dihimpun oleh peneliti dari berbagai informan yang terkait dengan aktifitas tersebut, dapat disimpulkan bahwa pengambilan keputusan kepailitan suatu perusahaan sangat sederhana, apabila bukti utang ada, dapat dinyatakan pailit walaupun aset yang perusahaan miliki lebih besar daripada utang.

Apabila permohonan perkara kepailitan perusahaan tersebut dikabulkan oleh hakim pengawas, maka perusahaan tersebut mempunyai kesempatan untuk melakukan upaya hukum kepailitan. Upaya hukum tersebut adalah dengan cara mengajukan kasasi ke Mahkamah Agung.

Peninjauan kembali dapat diajukan terhadap putusan hakim yang telah memperoleh kekuatan hukum tetap, dengan mengajukan ke Mahkamah Agung.

Selanjutnya adalah tahap mencocokan utang piutang di pengadilan, pada tahap ini sudah mulai terlihat adanya peran akuntansi forensik pada kepailitan, yaitu dimana adanya penelusuran mengenai kebenaran adanya utang piutang antara kreditor dan debitur apabila bukti yang dibawa oleh debitur dan kreditor tidak menemui kecocokan. Di sini dicari faktur-faktur yang membuktikan perjanjian mengenai utang piutang yang melibatkan minimal dua kreditor dan salah satu utangnya sudah jatuh tempo. Akuntansi forensik dibutuhkan dalam menelusuri apakah perusahaan tersebut benar-benar tidak dapat membayar utang kepada para kreditornya atau biasa disebut dengan insolvensi. Seperti yang diungkapkan oleh informan 1 bahwa "Ketika dapat dibuktikan adanya dua orang kreditor dan salah satu utangnya sudah dapat ditagih, maka perusahaan tersebut 
dapat dikatakan pailit. Ada perusahaan yang benar tidak bisa membayar utang tersebut, ada juga yang dikarenakan persaingan bisnis dimana biasanya perusahaan ini memiliki aset yang lebih besar daripada utangnya"

Hal senada juga diungkapkan oleh informan 6 mengenai mencocokkan utang piutang pada proses pengadilan, yaitu "Bukti utang piutang harus dibuktikan oleh kedua pihak pada saat persidangan untuk mengetahui apakah benar debitur mempunyai utang kepada kreditor."

Hasil reduksi catatan lapangan yang dikumpulkan peneliti ketika melakukan wawancara dengan informan mengenai peranan akuntansi forensik dalam mencocokkan utang piutang di pengadilan yang berhasil dihimpun oleh peneliti dari berbagai informan yang terkait dengan aktifitas tersebut, dapat disimpulkan bahwa akuntansi forensik dibutuhkan dalam menemukan bukti-bukti debitur mempunyai utang kepada kreditor, dengan adanya bukti tersebut, pihak pengadilan dapat mengambil keputusan mengenai pailit atau tidaknya perusahaan tersebut.

Penghitungan Aset dan Harta Kepailitan, dalam tahap ini sangat terlihat bahwa akuntansi forensik sangat berguna penerapannya karena dalam menghitung aset perusahaan perlu ditelusuri dimana saja keberadaan aset tersebut, lalu apakah nilai aset tersebut telah sesuai dengan yang ada di dokumen ataupun laporan keuangan perusahaan.Seperi yang diungkpapkan oleh informan 1 bahwa "dalam pekerjaannya, kurator dibantu oleh beberapa ahli seperti menggunakan jasa appraisal, akuntan publik, pajak, dan notaris." Kemudian berdasarkan wawancara dengan informan 2, didapatkan pernyataan bahwa "kita meminta cash flow perusahaan untuk mengetahui perusahaan tersebut untung atau merugi. Kurator tidak dapat bekerja sendiri, jadi bagian audit dia meminta bantuan akuntan publik."

Hasil reduksi catatan lapangan yang dikumpulkan peneliti ketika melakukan wawancara dengan informan mengenai peranan akuntansi forensik dalam penghitungan aset dan harta pailit yang berhasil dihimpun oleh peneliti dari berbagai informan yang terkait dengan aktifitas tersebut, dapat disimpulkan bahwa dalam penghitungan aset dan harta kepailitan akuntansi forensik sangat berperan. Karena dalam tahap ini, harus ditelusuri kebenaran nilai dari aset dan harta tersebut dan kebenaran dari keberadaannya. Dimana dalam menghitung aset kepailitian tersebut menggunakan harga pasar, karena apabila nilai bukunya nol bukan berarti tidak ada nilainya jika menggunakan harga pasar.

Dalam menghitung aset perusahaan yang bankrupt, akuntansi forensik juga dapat digunakan dalam menelusuri adanya indikasi fraud.. Informan 2 menyampaikan adanya kemungkinan fraud dalam perkara kepailitan suatu perusahaan seperti kutipan wawancara berikut ini: "Kadang juga misalnya debitur sudah dinyatakan pailit oleh hakim dan debitur berpikiran sudah tidak sanggup, debitur berusaha untuk mengamankan hartanya. Sebelum kurator bergerak, mungkin debitur membayar utang ke orang yang belum jatuh tempo atau debitur alihkan ke luar negeri. Itu dia mencoba untuk mengamankan aset debitur."

Selain itu juga informan 3 yang ahli dalam akuntansi forensik menyebutkan adanya indikasi fraud dalam kepailitan seperti berikut: "Karena banyak dari perusahaan yang mengalami bankrupt dikarenakan oleh adanya fraud. Mereka mengambil atau menyelamatkan uangnya, atau mereka mengambil asetasetnya, atau mereka menghancurkan dokumen-dokumen. Kita juga harus 
selection of supplier, yaitu kita harus mengetahui perusahaan yang akan menjadi supplier kita. Misalnya kita akan kerja sama dengan suatu perusahaan yang akan menjadi supplier, ternyata bulan depan manajernya membawa lari uang perusahaan, dan perusahaan yang menjadi supplier kita tersebut mengalami bangkrupt atau insolvency."

Hasil reduksi catatan lapangan yang dikumpulkan peneliti ketika melakukan wawancara dengan informan mengenai adanya indikasi fraud dalam kepailitan yang berhasil dihimpun oleh peneliti dari berbagai informan yang terkait dengan aktifitas tersebut, dapat disimpulkan bahwa kemungkinan besar akan terjadinya fraudpada suatu perusahaan yang mengalami bankrupt.Terdapat beberapa tipe fraud yang kemungkinan terjadi pada kasus kepailitan, yaitu (1) menggelapkan aset; (2) membawa lari aset; (3) menggelapkan aset; (4) mentransfer ke rekening lain.

Mencatat dan Mencocokkan Utang Piutang pada Saat Rapat Kredito, dalam tahap ini akuntansi forensik juga berperan, yaitu ketika mencari kebenaran adanya utang piutang antara debitur dan kreditor.Seperti yang diungkapkan oleh informan 6 "Kalau pembagian harta itu, itu nanti pemberesan. Pemberesannya itu nanti lama, ada rapat kreditor pertama dulu, abis rapat kreditor pertama, baru nanti dia pendataan dulu tagihan berapa yang masuk, sudah begitu diverifikasi dulu, diverifikasi benar tidak kreditor ini punya piutang. Terus kalau misalnya tidak sesuai, kata kreditor punya piutang lima tapi kata debitur cuma ada tiga, dipertemukan dulu namanya itu verifikasi."

Hal senada juga diungkapkan oleh informan 1, yaitu "utang piutang ini harus dicocokkan dengan dokumen, apakah sesuai atau tidak. Selain itu harus dicocokan juga dengan laporan keuangan apakah sesuai jumlahnya atau tidak."

Hasil reduksi catatan lapangan yang dikumpulkan peneliti ketika melakukan wawancara dengan informan mengenai peranan akuntansi forensik dalam mencatat dan mencocokkan utang piutang pada saat rapat kreditor yang berhasil dihimpun oleh peneliti dari berbagai informan yang terkait dengan aktifitas tersebut, dapat disimpulkan bahwa dalam tahap ini akuntansi forensik berperan juga. Hal ini dikarenakan dalam tahap ini, harus adanya penelusuran bukti utang piutang antara debitur dan kreditor. Apakah besarnya utang piutang tersebut sesuai dengan dokumen atau tidak, adanya jaminan atau tidak.

Dalam tahap ini akuntansi forensik mengambil peran, dimana ditentukan pembagian harta pailit kepada para kreditor berdasarkan urutan yang didapatkan dari penelusuran dan pencocokkan bukti utang piutang, apakah kreditor tersebut termasuk kreditor separatis, preferen, dan lainnya.Informan 4 memberikan pernyataan bahwa "ada urutan kewajiban nantinya yang lebih utama untuk dibayarkan misalnya perbankan merupakan kreditor pertama yang harus dipenuhi sehubungan dengan jaminan dan dalam perjanjiannya dia yang utama harus mendapatkan". Hal tersebut juga dikuatkan oleh pernyataan informan 1, yaitu "pembagian harta yang harus diutamakan adalah pembayaran pajak, kemudian bank, leasing, kemudian kepada para kreditor lainnya dimulai dari kreditor preferen dan lain-lain."

Hasil reduksi catatan lapangan yang dikumpulkan peneliti ketika melakukan wawancara dengan informan mengenai peranan akuntansi forensik dalam membagikan harta pailit yang berhasil dihimpun oleh peneliti dari berbagai informan yang terkait dengan aktifitas tersebut, dapat disimpulkan bahwa 
akuntansi forensik berperan dalam tahap ini. Hal ini karena dalam membagikan harta pailit diperhatikan juga urutan pembagian berdasarkan jaminan utang piutang, yang mengakibatkan adanya urutan kreditor separatis, preferen, dan kongruen.

Dari penjelasan di atas mengenai penerapan akuntansi forensik kasus kepailitan, dapat diketahui bahwa akuntansi forensik memang dibutuhkan dan digunakan dalam menyelesaikan kasus kepailitan.Itu terlihat dari berbagai hasil wawancara yang menunjukkan perlu adanya akuntansi forensik di beberapa tahapan dalam kasus kepailitan. Hal ini tidak terlepas dari keterkaitan perusahaan yang pailit dengan angka, utang piutang, laporan keuangan, aset, dan hal lain yang berhubungan dengan akuntansi. Selain itu adanya berbagai motif kecurangan yang mungkin muncul dibalik terjadinya kepailitan suatu perusahaan, menguatkan bahwa akuntansi forensik dibutuhkan dan tidak lepas dari kasus kepailitan.Namun dalam praktiknya, penggunaan akuntansi forensik masih jarang menangani kasus kepailitan di Indonesia karena disebabkan oleh berbagai alasan, seperti (1) membutuhkan waktu yang lama; (2) biaya yang mahal; (3) kurangnya sumber daya manusia.

\section{Simpulan}

Berdasarkan hasil penelitian yang peneliti lakukan terhadap "Akuntansi Forensik Dalam Praktik Kepailitan pada Pangadilan Niaga" maka peneliti menarik kesimpulan akuntansi forensik berperan dalam beberapa proses dalam perkara kepailitan. Hal ini dapat dilihat dari beberapa tahapan atau proses penyelesaian perkara kepailitan yang dilakukan di pengadilan niaga, diperlukan penelusuran yang berkaitan dengan akuntansi. Seperti dalam beberapa tahapan berikut, yaitu (1) Pada tahap Pengadilan Tingkat Pertama; (2) Pada tahap Kasasi dan Peninjauan Kembali; (3) Pada tahap Penghitungan Aset dan Harta Pailit; (4) Pada tahap Mencatat dan Mencocokkan Utang Piutang akuntansi forensik pada saat rapat kreditor; (5) Pada tahap Pembagian Harta Pailit. Akuntansi forensik juga dapat mendeteksi adanya indikasi fraud dalam hal pailit di Pengadilan Niaga, perusahaan yang benar-benar mengalami bankrupt cenderung untuk melakukan fraud dalam menyembunyikan asetnya ataupun deposito yang masih dimiliki oleh perusahaan. Hal ini bertujuan untuk mengamankan aset maupun deposito sehingga tidak disita oleh Pengadilan Niaga.Terdapat beberapa tipe fraud yang kemungkinan terjadi pada kasus kepailitan adalah (1) membawa lari aset; (2) menyembunyikan aset; (3) menggelapkan penjualan; (4) mentransfer ke rekening lain.

Terdapat kendala dalam menerapkan akuntansi forensik dalam perkara kepailitan, yang pertama yaitu waktu yang dibutuhkan dalam menerapkan akuntansi forensik relatif lama karena dalam menerapkan akuntansi forensik tidak menggunakan sampel melainkan populasi, namun dalam menentukan populasi juga harus bisa menentukan mana yang prioritas dan penting untuk kita periksa. Kemudian biaya yang harus dikeluarkan juga mahal, hal ini disebabkan oleh waktu yang lama dan ruang lingkup yang luas dalam menerapkan akuntansi forensik. Selain itu sumber daya yang masih kurang menjadi kendala yang lainnya, kurangnya pelatihan dan pengenalan mengenai akuntansi forensik kepada kurator atau perangkat pengadilan niaga menyebabkan masih awamnya 
pemahaman dan penerapan akuntansi forensik dalam praktik kepailitan di pengadilan niaga.

\section{Saran}

Untuk peneliti selanjutnya disarankan untuk melakukan observasi secara aktif untuk mengetahui secara komprehensif mengenai proses kepailitan. Peneliti selanjutnya juga dapat mengkaitkan penggunaan akuntansi forensik dalam membuktikan tindakan pencucian uang (money laundry).

\section{Daftar Pustaka}

Albrecht, W. Steve dan Chad O. Albrecht. 2003. Fraud Examination. Ohio: South-Western.

Amin Widjaja Tunggal. 2012. Forensic \& Investigative Accounting Pendekatan Kasus. Jakarta: Harvarindo.

Arens, Alvin et al. 2008. Auditing dan Jasa Assurance. Jakarta: Erlangga.

Ayu Prima Sandi. 2013. BPKP Targetkan 50 Auditor Forensik Baru. Tempo (Online). Tersedia: http://www.tempo.co/read/news/2013/04/11/ 087472658/BPKP-Targetkan-50-Auditor-Forensik-Baru (23 Agustus 2013)

Bungin, Burhan. 2010. Penelitian Kualitatif: Komunikasi, Ekonomi, Kebijakan Publik, dan Ilmu Sosial Lainnya. Jakarta: Kencana.

Cahyani, Ajeng R. 2012. Memahami Audit Forensik. (Online). Tersedia: http://www.jtanzilco.com/main/index.php/component/content/article/1kap-news/841-memahamiauditforensik. Hotml (18 Mei 2013)

Dian Dara Swarna. 2012. Penerapan Akuntansi Forensik dan Audit Investigasi dalam Mendeteksi Fraud di Lingkungan Digital. Skripsi. Medan: Universitas Sumatera Utara.

Franceschetti, Bruno Maria and Claudia Koschtial. 2013. Do Bankrupt Companies Manipulate Earning More Than The Non-Bankrupt Ones?.Journal of Finance and Accountancy.

Indra Sastrawat. 2011. Akuntansi Forensik dalam Kasus Century. Kompas (Online). http://ekonomi.kompasiana.com/moneter/2011/02/19/akuntansi-forensikdalam-kasus-century-341211.html (23 Agustus 2013)

J. Tanzil. 2011. Efektivitas Akuntan Forensik Dalam Membantu Mengungkap Korupsi di Indonesia. (Online). Tersedia: http://www.jtanzilco.com/main/index.php/component/content/article/1kap-news/31-akuntatan-forensik (25 Agustus 2013)

Jumansyah, dkk. 2011. Akuntansi Forensik dan Prospeknya Terhadap Penyelesaian Masalah-Masalah Hukum di Indonesia. Prosiding Seminar Nasional "Problematika Hukum dalam Implementasi Bisnis dan Investasi (Perspektif Multidisipliner)".

Luqman Hakim. 2007. Analisis Pemantauan Outcome Program Bantuan Operasional Sekolah (BOS) di Madrasah Tsanawiyah Gresik. Tesis. Malang: Universitas Muhammadiyah Malang.

Maria Yuniar. 2013. Ini Penyebab Batavia Air Dinyatakan Pailit. Tempo (Online). 
http://www.tempo.co/read/news/2013/01/30/090458040/Ini-Penyebab-

Batavia-Air-Dinyatakan-Pailit (20 Juni 2013)

Moleong, Lexy J. 2007. Metodologi Penelitian Kualitatif Edisi Revisi. Bandung: Remaja Rosdakarya.

Nina Kasih Puspita. 2009. Kewenangan Pengadilan Niaga Untuk Mengadili Perbuatan Melawan Hukum Oleh Kurator Dalam Pengurusan Harta Pailit. Tesis. Semarang: Universitas Diponegoro.

Purhantara, Wahyu. 2010. Metode Penelitian Kualitatif Untuk Bisnis. Yogyakarta: Graha Ilmu.

Ratih Siti R. 2011. Pengaruh Penerapan Akuntansi Forensik Terhadap Kompetensi Bukti Tidak Pidana Korupsi. Skripsi. Bandung: Universitas Padjadjaran.

Rezaee, Zabihollah and Riley Richard. 2010. Financial Statement Fraud: Prevention and Detection Second Edition. New Jersey: John Wiley \& Sons, Inc.

Siti Kurnia Rahayu dan Ely Suhayati. 2010. Auditing Konsep Dasar dan Pedoman Pemeriksaan Akuntan Publik. Yogyakarta: Graha Ilmu.

Sembiring, Sentosa. 2006. Hukum Kepailitan Dan Peraturan PerundangUndangan yang Terkait Dengan Kepailitan. Bandung: Nuansa Aulia.

Shubhan, M. Hadi. 2012. Hukum Kepailitan: Prinsip, Norma, dan Praktik di Peradilan. Jakarta: Kencana.

Singleton, Tommie W. dan Aaron J. Singleton. 2010. Fraud Auditing and Forensic Accounting Fourth Edition. New Jersey: Wiley.

Sugiyono. 2010.MetodePenelitianPendidikan (PendekatanKuantitatif, Kualitatif, dan $R \& D)$. Bandung: Alfabeta.

. 2011. Metode Penelitian Pendidikan (Pendekatan Kuantitatif, Kualitatif, dan $R \& D)$. Bandung: Alfabeta.

Sutedi, Adrian. 2009. Hukum Kepailitan. Bogor: Ghalia Indonesia.

Tuanakotta, Theodorus M. 2007. Akuntansi Forensik dan Audit Investigatif. Jakarta: Lembaga Penerbit Fakultas Ekonomi Universitas Indonesia. 2013. Mendeteksi Manipulasi Laporan Keuangan. Jakarta: Salemba Empat.

Undang-Undang Nomor 4 Tahun 1998 tentang penetapan Peraturan Pemerintah Pengganti Undang-Undang Nomor 1 Tahun 1998.

Undang-Undang Nomor 37 Tahun 2004 tentang Kepailitan dan Penundaan Kewajiban Pembayaran Utang.

Usman, Rachmadi. 2004. Dimensi Hukum Kepailitan di Indonesia. Jakarta: Gramedia Pustaka Utama.

www.pn-jakartapusat.go.id 